\title{
ANALISIS PENGARUH EFISIENSI DAN KECUKUPAN MODAL TERHADAP KINERJA KEUANGAN PADA BANK PEMBANGUNAN DAERAH DI INDONESIA
}

\author{
Sparta \\ STIE Indonesia Banking School \\ sparta@ibs.ac.id
}

This study aims to investigate the efficiency of Indonesian regional development banks (BPD) and the effects of efficiency, capital adequacy, bank size, and macroeconomic indicators on the performance of BPDs in 2008-2012. Our variables of interests are BOPO, CAR, LNSIZE, PDRB, GCRED and INF. We analyze these variables on 130 firm-year observations using the OLS with panel data. Our findings show that on average the BOPO of our BPD sample is $72.45 \%$. During that period, $B P D$ Sulawesi Selatan (BPD Aceh) is the most (least) efficient BPD as indicated by its BOPO of $54.03 \%$ (92.98\%). Next, our year-to-year analysis reveals that the most (least) efficient BPDs for the year 2008, 2009, 2010, 2011, and 2012 are BDKI, BSTR,BACH, BSUA, and BSSN (BSST, BSTA, BKTm, BSTA, and BSTA), respectively. Our study also indicates that none of BPD in Java have assets higher than their counterparts outside Java that are the most efficient BPDs for the whole Indonesia. Finally, we find that BOPO, CAR, LNSIZE, and GCREDR negatively affect BPDs' financial performance while INFR is positively associated with financial performance. However, GPDRBT has no significant effect on BPDs' financial performance.

Keyword: $B O P O, C A R$, financial performance.

\begin{abstract}
ABSTRAK
Penelitian ini bertujuan untuk mengetahui gambaran efisiensi BPD di Indonesia dan pengaruh efisiensi, kecukupan modal, ukuran bank dan indikator makro ekonomi terhadap kinerja BPD di Indonesia periode 2008-2012. Variabel-variabel yang dianalisis dalam riset ini adalah BOPO, CAR, LNSIZE, PDRB, GCRED dan INF. Alat analisis yang digunakan adalah OLS dengan data panel. Jumlah observasi dalam studi ini adalah sebanyak 130 . Hasil penelitian menunjukkan bahwa efisiensi bank BPD di Indonesia selama periode 2008-2012, yang ditunjukkan oleh rata-rata BOPO, adalah 72,45 persen. Selama periode tersebut, BPD Aceh mendapat predikat bank paling tidak efisien dengan BOPO 92,98 persen dan BPD Sulawesi Selatan mendapat predikat bank BPD paling efisien dengan BOPO 54,03 persen. Bank BPD paling efisien untuk tahun 2008, 2009, 2010, 2011 dan 2012 berturut adalah BDKI, BSTR, BACH, BSUA dan BSSN. Sedangkan bank BPD paling tidak efisien untuk tahun 2008, 2009, 2010, 2011, dan 2012 berturut-turut adalah BSST, BSTA, BKTm, BSTA dan BSTA. Hasil penelitian ini menunjukkan bahwa tidak ada satupun bank BPD di pulau jawa yang memiliki total aset lebih besar dibandingkan bank BPD di luar jawa yang mendapatkan predikat bank BPD paling efisien di Indonesia. Hasil penelitian ini juga menunjukkan bahwa BOPO, CAR, LNSIZE, dan GCREDR secara signifikan berpengaruh negatif pada kinerja keuangan bank BPD. INFR ditemukan berpengaruh
\end{abstract}


secara signifkan dan positif terhadap kinerja keuangan BPD. Sementara itu, GPDRBT tidak memiliki pengaruh signifikan pada kinerja keuangan BPD.

Kata Kunci: BOPO, CAR, kinerja keuangan.

\section{PENDAHULUAN}

Dalam periode setelah krisis (setelah tahun 2002), kondisi perbankan mulai berangsur pulih kembali. Hal ini terlihat dari kinerja perbankan nasional yang mulai membaik dibandingkan dengan periode krisis (Bank Indonesia 2008). Kinerja perbankan nasional mengalami perbaikan mengindikasikan bahwa adanya upayaupaya perbankan untuk memulihkan kinerja pasca krisis. Kinerja keuangan membaik dapat dilakukan dari dua sisi, yaitu sisi pendapatan operasional dan sisi biaya operasional bank. Indikator efisiensi beban operasional bank selama ini dilihat dari rasio beban operasional dibagi dengan pendapatan operasional atau disingkat dengan BOPO (Endri 2008).

Fungsi Intermediari Bank adalah sebagai penghimpun dana (input) dan penyalur dana (output). Penghimpunan dana bank dilakukan melalui dana pihak ketiga seperti giro, tabungan, dan deposito. Sebagian besar bank lebih mengandalkan sumber dana dari pihak ketiga ini. Lebih jauh posisi penghimpunan dan penyaluran dana dapat dilihat pada tabel 1.

Data statistik mengenai kinerja perbankan yang diterbitkan oleh Bank Indonesia tahun 2011 (tabel 2) terlihat bahwa ROA perbankan nasional meningkat sejak tahun 2001 sampai dengan 2011. Dari sisi ROA terlihat kinerja perbankan Indonesia mengalami peningkatan, namun dilihat dari BOPO, maka kinerja ini belum optimal.

Tingkat efisiensi perbankan Indonesia dibandingkan dengan bank-bank di negara lain masih rendah. Rasio BOPO perbankan di Indonesia sejak tahun 2001 sampai dengan 2011, rasio BOPO selalu berada di atas 84 persen pada tahun-tahun selain 2004 selama periode tersebut. Dibandingkan dengan negara tetangga seperti Malaysia, Singapura, dan Thailand yang berada di bawah 70 persen (Bank Indonesia 2011), angka BOPO perbankan di Indonesia relatif masih tinggi.

Penelitian yang mengaitkan kinerja keuangan perbankan menggunakan rasio keuangan dengan efisiensi menggunakan metode frontier adalah Bonin et al. (2003). Bonin et al. (2003) menggunakan rasio kinerja bank dengan ROA dan ROE, kemudian mengaitkannya dengan efisiensi bank menggunakan SFA. Hasilnya bank dengan ROA tinggi mempunyai hubungan positif signifikan dengan tingkat efisiensi (dengan menggunakan SFA). Penelitian Nigmonov (2010) menggunakan kinerja bank melalui rasio revenue terhadap aset bank. Penelitian Micco et al. (2005) juga menggunakan ROA sebagai variabel standar kinerja bank. Magalhaes et al. (2010) menggunakan ROA sebagai variabel kinerja bank. Penelitian Fiorentino et al. (2006) 
juga menggunakan variabel ROA sebagai standar pengukuran kinerja perbankan dan mengaitkannya dengan kinerja efisiensi bank menggunakan DEA dan SFA. Mirnawati (2007) menggunakan kinerja rasio keuangan ROA dikaitkan dengan kinerja perbankan menggunakan DEA. Alfarisi (2008) menggunakan kinerja keuangan bank ROE untuk melihat hubungannya dengan kinerja efisiensi bank di Indonesia. Dari sebagian penelitian tersebut menunjukkan adanya hubungan signifikan antara efisiensi menggunakan metode frontier dan kinerja keuangan bank ROA, sedangkan sebagian lainnya menunjukkan tidak ada hubungan.

Bagaimana hubungan efisiensi dengan kinerja perbankan dengan menggunakan pengukuran efisiensi tradisional? Hasil studi Sudiyatno dan Suroso (2010) menggunakan ukuran efisiensi tradisional BOPO dikaitkan dengan variabel ROA sebagai indikator kinerja keuangan bank, hasilnya BOPO mempunyai pengaruh negatif signifikan terhadap kinerja keuangan bank (ROA). Penelitian Sudiyatno dan Setyowati (2012) dengan tahun berbeda juga menunjukkan yang sama bahwa BOPO signifikan negatif mempengaruhi ROA.

Peraturan Bank Indonesia No.10/15/PBI/2008 tanggal 24 September 2008 tentang Kewajiban Penyedian Modal Minimum Bank Umum dalam pasal 2 ayat 1 menyatakan "Bank wajib menyediakan modal minimum sebesar 8 persen dari aset tertimbang menurut risiko (ATMR)" (http://www.bi.go.id ). Dengan ketentuan ini telah mendorong tambahan modal oleh pemilik sehingga bank dapat memperluas operasi dan meningkatkan kepercayaan deposan.

Modal bank yang cukup menutup tingkat risiko aset kemungkinan dapat meningkatkan kinerja bank tersebut (Rose 2002). Hal ini disebabkan adanya peningkatan tingkat kepercayaan dari deposan untuk menitipkan dananya meski tingkat suku bunga dana pihak ketiga lebih rendah. Dari sisi aset, tingkat kecukupan modal yang tinggi akan memberikan kesempatan diversifikasi aset bagi bank dan dapat melakukan ekspansi sehingga dapat meningkatkan kemampuan profitabilitas bank yang akhir meningkatkan kinerja keuangan bank (Rose 2002). Kecukupan modal bank dapat mempengaruhi kinerja bank tersebut (Mester 1993; Pastor et al., 1997; Carbo et al., 1999; dan Girardone et al., 2004). Di Indonesia hasil penelitian kecukupan permodalan (CAR), juga mempengaruhi positif terhadap kinerja perbankan (Sudiyatno \& Suroso 2010). Sedangkan hasil penelitian Sudiyatno dan Setyowati (2012), menyatakan sebaliknya CAR tidak signifikan mempengaruhi kinerja perbankan.

Lebih jauh, indikator makroekonomi yang mengambarkan kinerja ekonomi makro suatu negara dapat mempengaruhi kinerja perbankan. Hal ini sesuai hasil penelitian yang dilakukan Chen (2001) yang meneliti sejauh mana kinerja perbankan di Amerika Serikat dapat dipengaruhi oleh variabel makroekonomi GDP negara tersebut. Hasilnya menunjukkan kondisi makroekonomi mempengaruhi signifikan positif kinerja bank kecil, sedangkan bank besar kondisi ekonomi makro tidak 
mempengaruhi kinerja perbankan. Hal ini karena bank besar memiliki portfolio yang lebih diversifikasi dibandingkan dengan bank kecil. Pengaruh positif GDP terhadap kinerja perbankan juga ditemukan oleh beberapa peneliti lain diantaranya Iannotta et al. (2006); Beck dan Hesse (2006); Bonin et al. (2003). Apabila dilihat dari ukuran BPD di Indonesia dikaitkan dengan bank yang ada di Amerika, maka BPD di Indonesia masuk dalam skala bank kecil. Dengan demikian, perlu dilakukan pengujian apakah indikator makroekonomi GDP dapat mempengaruhi kinerja BPD di Indonesia.

Bank Pembangunan Daerah (BPD) merupakan bank dimiliki mayoritas oleh pemerintah daerah setempat. BPD saat ini sebagian sudah beroperasi di provinsi lain. Hal ini menunjukkan adanya ekspansi operasional BPD dari yang hanya beroperasi dalam provinsinya saja, sekarang telah meluas ke provinsi lain. Contoh diantaranya adalah BPD Sumatera Barat (Bank Nagarai), BPD Jateng, BPD Sumut, BPD Jabar dan Banten, dan lain-lain. Perluasan area operasioanl BPD tentu membawa konsekuensi pada kecukupan modal, efisiensi, dan kinerja BPD itu sendiri. Berdasarkan hal ini peneliti tertarik untuk meneliti bagaimana efisiensi, kecukupan modal, dan kinerja operasinya sejak tahun 2008 sampai dengan tahun 2012. Kemudian penelitian ini juga melihat apakah ada pengaruh kecukupan modal dan efisiensi terhadap kinerja operasi BPD. Variabel kontrol yang digunakan adalah indikator ekonomi makro terhadap kinerja BPD. Kemudian untuk melihat apakah ukuran bank juga mempengaruhi kinerja BPD, maka ukuran BPD digunakan sebagai variabel kontrol untuk melihat hubungan efisiensi, kecukupan modal terhadap kinerja BPD di seluruh Indonesia.

Penelitian ini hanya melihat periode data tahunan sejak tahun 2008 sampai dengan tahun 2012. Penelitian ini tidak menggunakan data sebelum 2008 karena karakteristik data perbankan sebelum 2008 berbeda dibandingkan setelah 2008. Hal ini karena adanya krisis keuangan yang terjadi tahun 2008 dan 2009. Sedangkan data setelah tahun 2012 tidak digunakan dalam penelitian karena diasumsikan kondisi perbankan setelah tahun 2012 berbeda dibandingkan tahun 2008 dan 2012. Hal ini karena setelah tahun 2012 sampai tahun 2015 terjadi penurunan GDP Indonesia. Ukuran efisiensi yang digunakan adalah BOPO. Ukuran kecukupan modal adalah CAR dan ukuran kinerja operasional adalah ROA. Variabel makro yang digunakan adalah GDP, inflasi, pertumbuhan kredit. Variabel kontrol lainnya adalah ukuran bank, yaitu total aset. Bank yang diteliti adalah BPD seluruh Indonesia.

Pokok permasalahan yang diangkat dalam penelitian ini, yaitu 1). Bagaimana gambaran efisiensi BPD di Indonesia periode 2008-2012; 2). Seberapa besar pengaruh efisiensi, kecukupan modal terhadap kinerja BPD di Indonesia periode 2008-2012; 3). Seberapa besar pengaruh indikator makroekonomi dari pertumbuhan PDRB tahun sebelumnya, pertumbuhan kredit dan inflasi mempengaruhi kinerja keuangan BPD sekarang di Indonesia periode 2008-2012; dan 4). Seberapa besar pengaruh ukuran BPD mempengaruhi kinerja BPD periode 2008-2012 . 
Tujuan penelitian ini adalah untuk mengetahui dan menganalisis: 1). Gambaran efisiensi BPD di Indonesia periode 2008-2012; 2). Pengaruh efisiensi, kecukupan modal terhadap kinerja BPD di Indonesia periode 2008-2012; 3). Pengaruh indikator makro terhadap kinerja BPD di Indonesia periode 2008-2012; dan 4). Pengaruh ukuran BPD terhadap kinerja keuangan BPD periode 2008-2012.

Hasil penelitian ini diharapkan dapat bermanfaat: 1). Bagi akademisi, hasil penelitian ini sebagai salah satu bentuk pembuktian empiris yang dapat digunakan dalam pengembangan ilmu pengetahuan khusus pengaruh efisiensi, kecukupan modal, ukuran bank, indikator makro PDRB, pertumbuhan kredit, dan inflasi terhadap kinerja keuangan BPD di Indonesia; 2). Bagi Otoritas Jasa Keuangan (OJK) atas data empiris hasil penelitian ini dapat digunakan sebagai dasar evaluasi dan dasar kebijakan terkait dengan efisiensi BPD dan persyaratan kecukupan modal serta pengawasan operasional BPD di Indonesia; dan 3). Bagi praktisi yang ada di BPD, hasil penelitian ini dapat digunakan sebagai dasar dalam mengestimasi kinerja keuangannya dengan menggunakan hasil model prediksi persamaan penelitian ini.

\section{KAJIAN PUSTAKA DAN PERUMUSAN HIPOTESIS}

\section{Kinerja Perbankan}

Dalam evaluasi kinerja lembaga keuangan harus dipisahkan setiap unit produksi dengan menggunakan standard perform yang lebih baik (Berger dan Humphrey 1997). Hal ini dilakukan dengan menerapkan non-parametric frontier analysis atau parametric frontieranalysis pada industri keuangan.

Indikator penilaian kinerja perbankan di Indonesia oleh Bank Indonesia berdasarkan rasio-rasio Capital Adequacy Ratio, Gross Non Performing Loan, Return On Asset, Net Interest Margin, BOPO, dan Loan Deposit Ratio (Bank Indonesia 2011). Dalam penelitian ini indikator kinerja yang digunakan adalah Return On Asset. Alasan digunakan rasio ini sebagai ukuran kinerja karena sudah mengaitkan total hasil bersih yang dicapai dengan aset yang dikorbankan untuk memperoleh hasil bersih tersebut. Rasio ini sudah mencakup semua hasil yang diperoleh dari aktivitas operasi, pembiayaan, dan investasi (Subramanyam \& Wild 2009).

Dalam penelitian ini kinerja keuangan perbankan yang digunakan adalah Return On Asset (ROA). ROA menggambarkan imbal hasil yang dapat diberikan perusahaan kepada penyandang dana (Subramanyam \& Wild 2009). ROA disebut juga imbal hasil dari sisi perspektif semua penyandang dana. Rasio lain yang sering digunakan dalam penilaian kinerja keuangan bank adalah Return On Equity (ROE). Rasio ROE digunakan dalam penelitian ini. Rasio ROE menggambarkan imbal hasil yang akan diberikan kepada pemegang saham sehingga ROE disebutkan juga imbal dari sisi perspektif pemegang saham perusahaan. 
Dapat diartikan bahwa penilaian kinerja perbankan dapat dilihat dari sisi rasio keuangan dan sisi efisiensi bank. Dalam penelitian Mirnawati (2007) menunjukkan bahwa penggunaan gabungan kedua sisi ini dalam menilai kinerja bank dapat bermanfaat bagi manajemen untuk menilai ketidakefisienan bank. Dalam penelitian ini dilihat apakah ada hubungan kinerja efisiensi bank dengan kinerja bank menggunakan rasio keuangan. Hasil-hasil penelitian terdahulu menunjukkan adanya hubungan yang erat antara kinerja rasio keuangan dengan kinerja efisiensi (Mirnawati 2007).

\section{Efisiensi Perbankan}

Efisiensi perbankan diukur dengan menghitung perbedaan antara biaya yang dikeluarkan perbankan dengan biaya minimum yang seharusnya dikeluarkan oleh bank untuk menghasilkan output yang sama (Mardanugraha 2005). Penilaian efisiensi bank juga diukur dari biaya yang dikeluarkan oleh bank dibandingkan dengan biaya yang dikeluarkan berdasarkan best practice bank. Efisiensi bank dapat diartikan rasio biaya minimum di mana bank dapat menghasilkan sejumlah output tertentu, dengan biaya sebenarnya yang dikeluarkan bank tersebut (Hartono 2009). Biaya minimum diperoleh dari estimasi fungsi biaya minimum perbankan. Efisiensi bank dapat dibagi dua (Farel 1957 dan Fiorentino et al., 2006), yaitu technical efficiency (efisiensi teknis) dan allocative efficiency (efisiensi alokatif).

Terdapat beberapa metode pengukuran efisiensi perbankan yang telah dilakukan selama ini (Hartono 2009), yaitu 1). Traditional Approach, mengunakan Index Number atau rasio (BOPO); dan 2). Frontier Approach didasarkan pada perilaku optimal dari perusahaan guna memaksimumkan output atau meminimumkan biaya, sebagai cara unit ekonomi untuk mencapai tujuan. Pada pendekatan Frontier Approach terdapat beberapa pendekatan, yaitu 1). Deterministic Approach: sering digolongkan sebagai Pendekatan Non-Parametrik, pendekatan ini menggunakan Tekhnical Mathematic Programing, atau populer dengan Data Envelopment Analysis (DEA); dan 2). Stochastic Approach: Pendekatan ini digolongkan sebagai pendekatan parametrik, menggunakan Econometric Frontier.

Penelitian ini menggunakan pendekatan tradisional dalam mengukur efisiensi, yaitu menggunakan BOPO. BOPO digunakan dalam pengukuran efisiensi dalam penelitian ini, pertama, karena rasio ini digunakan oleh Bank Sentral sebagai penilaian efisiensi perbankan, termasuk regulator Otoritas Jasa Keuangan (OJK). Kedua, rasio BOPO lebih mudah dipahami sebagai ukuran efisiensi perbankan oleh industri perbankan. Ketiga, rasio BOPO tidak memerlukan pengukuran yang rumit, namun cenderung lebih sederhana.

\section{Efisiensi dan Kinerja Keuangan Perbankan}

Hubungan kinerja keuangan menggunakan ROA dan efisiensi dapat dijelaskan dari Formulasi ROA (Subramanyam \& Wild 2009; White et al., 2003; Robinson et al., 2004; Fraser \& Ormiston 2007). 
$R O A=\frac{N I A T}{\text { Average } T A}$

Formulasi ROA dapat didekomposisi sebagai berikut:

$R O A=\frac{\text { NIAT }}{\text { Sales }} \times \frac{\text { Sales }}{\text { Average } T A}$

Semakin efisien operasi perusahaan dan semakin tinggi efisiensi pemanfaatan aset perusahaan, maka kemampuan perusahan untuk memberikan imbal hasil kepada semua penyandang dana akan semakin tinggi juga. Pengukuran efisiensi operasi dan efisiensi pemanfaatan aset tersebut di atas didasarkan kepada rasio keuangan perusahaan. Imbal hasil kepada semua pemegang dana sering digunakan sebagai dasar ukuran kinerja standar perusahaan adalah ROA, sedangkan imbal hasil kepada pemegang saham adalah ROE. Dengan demikian terdapat kaitan efisiensi operasi dan efisiensi pemanfaatan aset (menggunakan rasio keuangan NPM dan Turn Over Asset) dengan ROA dan ROE (Subramanyam dan Wild 2009). Variabel ROA, ROE, NPM, dan turn over aset merupakan rasio keuangan yang digunakan sebagai ukuran kinerja perusahaan.

Formulasi ROA di atas merupakan ukuran kinerja keuangan suatu entitas. Apabila formulasi ROA di atas dijabarkan lebih jauh untuk menggambarkan entitas perbankan, maka dapat didekomposisikan persamaan 2.2 di atas sebagai berikut:

$$
\begin{aligned}
& R O A_{t}=\frac{N I I_{t}}{\left(P_{t}+P N O_{t}\right)} \times \frac{\left(P_{t}+P N O_{t}\right)}{\text { Average } T A} \\
& \left.N I I_{t}=\left(P O_{t}-B O_{t}\right)+\left(P N O_{t}-B N O_{t}\right)-B O H_{t}-\text { Tax }_{t}\right)
\end{aligned}
$$

Dimana ROA adalah Return On Asset dari bank, NII adalah Net Interet Income bank, PO adalah Pendapatan Operasional bank, PNO adalah Pendapatan Non Operasional bank, BOH adalah Beban Over Head bank, dan tax adalah pajak.

Apabila formula 2.4 dimasukan ke dalam persamaan 2.3, maka menjadi sebagai berikut:

$R O A_{t}=\frac{\left.\left(P O_{t}-B O_{t}\right)+\left(P N O_{t}-B N O_{t}\right)-O H_{t}-T_{a x}\right)}{\left(P O_{t}+P N O_{t}\right)} \times \frac{\left(P O_{t}+P N O_{t}\right)}{\text { Average TA }}$

Misalkan dampak perubahan tingkat efisiensi (EFF) bank terhadap $P O_{t}$ dan $P N O_{t}$ adalah disimbolkan dengan $\alpha_{e f}$ dan $\beta_{e f}$, maka

$\alpha_{e f}=\frac{\Delta P O_{t}}{\Delta E F F}$

$\beta_{e f}=\frac{\Delta P N O_{t}}{\Delta E F F}$

Asumsikan bahwa $\alpha_{e f}, \beta_{e f}>0$, artinya kenaikan tingkat efisiensi bank akan meningkatkan pendapatan operasional dan pendapatan non operasional bank. Semakin efisien bank, maka pendapatan operasional semakin naik karena bank mampu menekan biaya operasional sehingga pendapatan operasional meningkat karena dapat menjual dananya lebih rendah dibandingkan bank lainnya. Dengan 
demikian, nilai PO setelah adanya perubahan tingkat efisiensi bank adalah $(1+$ $\left.\alpha_{e f}\right)$. Begitu juga nilai PNO setelah adanya perubahan tingkat eficiensi bank adalah $\left(1+\beta_{e f}\right)$.

Dampak perubahan tingkat efisiensi bank (EFF) terhadap BO, BNO, BOH, dan tax dapat dinyatakan sebagai berikut:

$\begin{aligned} \gamma_{e f} & =\frac{\Delta B O_{t}}{\Delta E F F} \\ \delta_{e f} & =\frac{\Delta B N O_{t}}{\Delta E F F} \\ \rho_{e f} & =\frac{\Delta B O H_{t}}{\Delta E F F} \\ \theta_{e f} & =\frac{\Delta T a x_{t}}{\Delta E F F}\end{aligned}$

Diasumsikan nilai $\gamma_{e f}, \delta_{e f}$ dan $\theta_{e f}<0$ artinya peningkatan efisiensi bank akan menurunkan beban bank. Dengan demikian, nilai BO, BNO, BOH, dan Tax setelah adanya perubahan efisiensi menjadi sebesar $\left(1-\gamma_{e f}\right),\left(1-\delta_{e f}\right),(1-$ $\left.\rho_{e f}\right)$, dan $\left(1-\theta_{e f}\right)$.

Peningkatan efisiensi menyebabkan pendapatan bank meningkat, beban menurun, dan akan berdampak pada peningkatan nilai aset bank. Dengan demikian, dampak efisiensi bank terdapat pertumbuhan aset bank adalah positif. Dampak perubahan tingkat efisiensi bank terhadap total aset dapat dinyatakan sebagai berikut:

$\vartheta_{e f}=\frac{\Delta \text { Total asset }_{t}}{\Delta E F F}$

Nilai aset bank setelah adanya perubahan efisiensi bank akan menjadi sebesar $(1+\vartheta)$. Artinya semakin tinggi perubahan tingkat efisiensi bank, maka total nilai asetnya akan semakin tinggi.

Berdasarkan dampak efisiensi terhadap komponen dalam ROA, maka dampak perubahan efisiensi terhadap ROA dapat dinyatakan dengan memasukan dampak perubahan efisiensi masing-masing komponen ke persamaan 2.5, sehingga menjadi sebagai berikut:

$$
\begin{aligned}
& \frac{\Delta R O A_{t}}{\Delta E F F}=\frac{\left.\left((1+\alpha) P O_{t}-(1-\gamma) B O_{t}\right)+\left((1+\beta) P N O_{t}-(1-\delta) B N O_{t}\right)-\left((1-\rho) B O H_{t}\right)-\left((1-\theta) T a x_{t}\right)\right)}{\left((1+\alpha) P O_{t}+(1+\beta) P N O_{t}\right)} \times \\
& \frac{\left((1+\alpha) P O_{t}+(1+\beta) P N O_{t}\right)}{(1+\vartheta) \text { Average TA }}
\end{aligned}
$$

Misalkan bahwa asumsi $\alpha_{e f}=\beta_{e f}=\gamma_{e f}=\delta_{e f}=\rho_{e f}=\theta_{e f}=\vartheta_{e f}$, maka dampak efisiensi terhadap ROA dapat diperoleh sebagai berikut: 


$$
\begin{aligned}
\frac{\triangle R O A_{t}}{\triangle E F F}= & \frac{\left.\left(\left(1+\alpha_{e f}\right) P O_{t}-\left(1-\alpha_{e f}\right) B O_{t}\right)+\left(\left(1+\alpha_{e f}\right) P N O_{t}-\left(1-\alpha_{e f}\right) B N O_{t}\right)-\left(\left(1-\alpha_{e f}\right) B O H_{t}\right)-\left(\left(1-\alpha_{e f}\right) T_{a x}\right)\right)}{\left(\left(1+\alpha_{e f}\right) P O_{t}+\left(1+\alpha_{e f}\right) P N O_{t}\right)} \times \\
& \frac{\left(\left(1+\alpha_{e f}\right) P O_{t}+\left(1+\alpha_{e f}\right) P N O_{t}\right)}{(1+\alpha) \text { Average } T A}
\end{aligned}
$$

maka

$\frac{\Delta R O A_{t}}{\Delta E F F}=\frac{\left.\left(\left(1+\alpha_{e f}\right)\left(P O_{t}+P N O_{t}\right)\right)-\left(\left(1-\alpha_{e f}\right)\left(B O_{t}\right)-B O H_{t}-T_{a x}\right)\right)}{\left(\left(1+\alpha_{e f}\right)\left(P O_{t}+P N O_{t}\right)\right.} \times \frac{\left(\left(P O_{t}+P N O_{t}\right)\right.}{\text { Average } T A}$

Sehingga:

$\frac{\Delta R O A_{t}}{\Delta E F F}=\left[1-\frac{\left(1-\alpha_{e f}\right)\left(B O_{t}-B O H-T a x\right)}{\left(\left(1+\alpha_{e f}\right)\left(P O_{t}+P N O_{t}\right)\right.}\right] \times \frac{\left(P O_{t}+P N O_{t}\right)}{\text { Average TA }}$

Bila kenaikan tingkat EFF menyebabkan $\alpha_{e f}<1$, maka kenaikan EFF akan menyebabkan ROA mengalami penurunan. Namun bila kenaikan EFF menyebabkan $\alpha_{e f}>1$, maka kenaikan EFF menyebabkan ROA mengalami kenaikan. Dengan demikian dampak efisiensi terhadap ROA dalam hal ini kinerja berdasarkan rasio keuangan bisa berdampak positif dan negatif, hal ini tergantung kepada sejauh mana dampak perubahan efisiensi terhadap perubahan komponen pendapatan dan beban. Bila dampak perubahan tersebut di bawah satu, maka kenaikan efisiensi menyebabkan ROA mengalami penurunan, namun bila di atas satu, maka kenaikan EFF akan menyebabkan ROA mengalami kenaikan. Diasumsikan bahwa $\alpha_{e f}>1$, yaitu setiap kenaikan tingkat efisiensi 1 persen menyebabkan komponen pendapatan naik dan beban turun lebih dari 1 persen. Dengan demikian, maka hubungan tingkat efisiensi dengan ROA adalah positif.

Beberapa penelitian sebelumnya menggunakan ukuran kinerja keuangan dengan ROA dan hubungan dengan efisiensi bank (metode frontier) diantaranya adalah Bonin et al., (2003). Hasilnya bank dengan ROA tinggi mempunyai hubungan positif signifikan dengan tingkat efisiensi. Penelitian lain yang menggunakan ukuran kinerja bank dengan ROA dikaitkan dengan efisiensi bank adalah Micco et al. (2005); Magalhaes et al. (2010); Mirnawati (2007); dan Alfarisi (2008) sedangkan penelitian lain yang mengkaitkan kinerja bank ROA dengan efisiensi menggunkan BOPO adalah Sudiyatno dan Suroso (2010) dan Sudiyatno dan Setyowati (2012), hasilnya BOPO mempunyai pengaruh negatif signifikan terhadap kinerja keuangan bank (ROA). Penelitian Fiorentino et al. (2006) juga menggunakan variabel ROA dikaitkan dengan kinerja efisiensi bank menggunakan DEA dan SFA. Penelitian Nigmonov (2010) menggunakan ukuran kinerja bank dengan rasio revenue terhadap aset bank dan dikaitkan dengan efisiensi bank. Dari sebagian penelitian tersebut menunjukkan adanya hubungan signifikan positif kinerja keuangan bank ROA terhadap efisiensi bank (menggunakan metode frontier dan tradisional). 


\section{Kecukupan Permodalan dan Kinerja Keuangan Bank}

Ketentuan permodalan bank dalam Basel Accord 1 tahun 1988, telah terbukti meningkat permodalan perbankan di Eropa (Fiordelisi et al., 2010). Ketentuan permodalan yang dikeluarkan oleh Bank International Setllement (BIS) ini juga diadopsi oleh Bank Indonesia dalam mengatur permodalan perbankan di Indonesia dalam mensyaratkan bahwa jumlah modal bank minimal 8 persen dari total aset bank yang berisiko yang disebut dengan ATMR (Aset Tertimbang Menurut Risiko).

Dalam Peraturan Bank Indonesia No.10/15/PBI/2008 tanggal 24 September 2008 tentang Kewajiban Penyedian Modal Minimum Bank Umum dalam pasal 2 ayat 1 menyatakan "Bank wajib menyediakan modal minimum sebesar 8 persen dari aset tertimbang menurut risiko (ATMR)". Dalam pasal 6 ayat 1, "Bank wajib menyediakan modal inti sebagaimana dimaksud dalam Pasal 4 ayat (1) huruf a paling kurang 5 persen dari ATMR baik secara individual maupun secara konsolidasi dengan Perusahaan Anak" (http://www.bi.go.id).

Modal bank yang cukup menutup tingkat risiko aset, maka kinerja bank akan membaik. Hal ini disebabkan adanya peningkatan tingkat kepercayaan dari deposan untuk menitipkan dananya meski tingkat suku bunga dana pihak ketiga lebih rendah. Dari sisi aset, tingkat kecukupan modal yang tinggi akan memberikan kesempatan diversifikasi aset bagi bank dan dapat melakukan ekspansi sehingga dapat meningkatkan kemampuan profitabilitas bank atau kinerja keuangan bank (Rose 2002).

Hasil penelitian Berger dan Bouwman (2009) menunjukkan bahwa tingkat permodalan bank pada bank kecil mampu bertahan pada saat market crisis dan banking crisis yang terjadi di dunia terutama di Amerika Serikat. Sedangkan bank menengah dan besar, tingkat permodalan hanya mampu bertahan saat banking crisis terjadi. Ini menujukan bahwa ada hubungan antara permodalan bank dengan kinerja perbankan tersebut. Hasil penelitian di Indonesia yang dilakukan oleh whSudiyatno dan Suroso (2010) menunjukkan kecukupan modal (CAR) mempunyai hubungan signifikan positif dengan kinerja perbankan. Sedangkan hasil penelitian yang berlawanan yang dilakukan oleh Sudiyatno dan Setyowati (2012) menunjukkan CAR tidak signifikan mempengaruhi kinerja bank.

\section{Ukuran Bank dan Kinerja Keuangan Bank}

Total aset dan total penjualan digunakan sebagai ukuran perusahaan. Semakin besar total aset dan penjualan perusahaan, maka semakin tinggi ukuran perusahaan (Subramanyam dan Wild 2009). Sebagian besar penelitian banyak menggunakan ukuran perusahaan dengan total aset perusahaan. Dalam penelitian ini ukuran bank menggunakan total aset bank.

Pada persamaan $R O A=\frac{\text { NIAT }}{\text { Sales }} \times \frac{\text { Sales }}{\text { Average TA }}$ terlihat bahwa total aset mempunyai hubungan negatif terhadap ROA atau kinerja perusahaan dengan asumsi NIAT dan 
sales tidak berubah apabila aset meningkat (Subramanyam dan Wild 2009). Namun dalam kenyataannya peningkatan nilai aset sering diiringi dengan peningkat NIAT dan sales sehingga peningkatan total aset dapat meningkatkan ROA.

\section{Indikator Makroekonomi dan Kinerja Keuangan Bank}

Chen (2001) menggunakan faktor-faktor makroekonomi sebagai variabel independen menjelaskan kaitan kinerja bank dengan makroekonomi di Amerika Serikat. Variabel makro yang digunakan adalah perubahan GDP, perubahan tingkat penggangguran, perubahan indikator ekonomi utama (penawaran uang M2), dan perbedaan tingkat suku bunga treasury bonds berjangka waktu 10 tahun dengan tingkat suku bunga Bank Sentral.

Studi yang dilakukan oleh Beck dan Hesse (2006) mengenai kinerja bank di Uganda tahun 1999-2005 menggunakan variabel independen makroekonomi (variabel GDP growth, real T-Bill rate, inflation, dan kurs rate). Kinerja bank menggunakan indikator perubahan spread dan margin bank. Perubahan kondisi ekonomi makro mempunyai explanatory power yang rendah dalam menjelaskan perubahan spread dan margin tidak signifikan.

Indikator makroekonomi GDP dapat mempengaruhi kinerja perbankan. Hasil penelitian Iannotta et al. (2006) menunjukan bahwa GDP signifikan positif mempengaruhi kinerja perbankan di 15 negara Eropa. Kinerja perbankan yang dipengaruhi oleh GDP adalah profit bank dan pendapatan bank. Semakin tinggi GDP suatu negara, maka semakin tinggi kinerja perbankan di negara tersebut. Menurut Rose dan Hudgins (2005), dampak GDP tahun sekarang terhadap kinerja perbankan baru terasa tahun berikutnya. Sehingga GDP tahun sekarang mempengaruhi kinerja perbankan tahun berikutnya.

Inflasi mempengaruhi suku bunga bank. Nominal suku bunga pinjaman bank sudah memasukkan inflasi (Rose 2002). Suku bunga real adalah suku bunga dikurangi dengan tingkat inflasi. Semakin tinggi inflasi, maka semakin tinggi tingkat suku bunga. Tingginya suku bunga akan mempengaruhi kinerja perbankan. Semakin tinggi inflasi, maka tingkat kinerja keuangan bank akan semakin rendah, hal ini disebabkan oleh peningkatan beban operasional bank dan biaya dana. Namun demikian apabila kenaikan inflasi dapat meningkatkan sisi pendapatan kredit lebih besar dari peningkatan beban bunga dan operasional bank, maka dampak kenaikan inflasi adalah positif terhadap kinerja bank.

Pertumbuhan kredit akan meningkatkan kinerja perbankan karena kredit merupakan aktiva produktif yang berdampak pada kenaikan pendapatan bunga bank (Rose 2002). Kenaikan pendapatan bunga tersebut akan meningkatkan kinerja operasional (kenaikan income) apabila perbankan dapat meningkatkan efisiensinya.

Berdasarkan kajian teori di atas, dengan ini hipotesis yang diajukan dalam penelitian untuk menjawab sementara permasalah penelitian adalah: 
H1: Efisiensi bank diduga berpengaruh terhadap kinerja keuangan perbankan BPD.

H2: Kecukupan modal diduga berpengaruh terhadap kinerja keuangan BPD.

H3: Ukuran BPD diduga berpengaruh terhadap kinerja keuangan BPD.

H4: Pertumbuhan produk domestik regional tahun sebelumnya diduga berpengaruh terhadap kinerja keuangan bank BBD tahun sekarang.

H5: Pertumbuhan kredit perbankan regional diduga berpengaruh terhadap kinerja keuangan bank.

H6: Inflasi regional diduga berpengaruh terhadap kinerja keuangan bank.

Kerangka pemikiran penelitian ini dapat dilihat pada Gambar 1 (Lampiran).

\section{METODA PENELITIAN}

Penelitian ini dilakukan untuk memperoleh data informasi tentang pengaruh efisiensi bank, kecukupan modal, ukuran bank, dan variabel makroekonomi PSDRB, inflasi, dan pertumbuhan kredit terhadap kinerja keuangan Bank Pembangunan Daerah seluruh Indonesia. Teknik pengumpulan datanya menggunakan data sekunder laporan keuangan BPD dan laporan ekonomi Bank Indonesia. Dalam persamaan penelitian ini, variabel bebasnya adalah efisiensi (BOPO) dan kecukupan modal (CAR). Variabel kontrolnya adalah variabel ukuran BPD (LNSIZE) dan variabel makro (PDRB, GCRED, INF). Definisi dan operasional variabel penelitian lihat Tabel 3 (Lampiran).

Populasi penelitian adalah industri perbankan. Dipilihnya industri perbankan karena dalam regulasi perbankan, penilaian efisiensi perbankan oleh Bank Sentral menjadi perhatian utama dan menentukan kinerja perbankan yang akan mempengaruhi kinerja sistem keuangan suatu negara. Industri perbankan terdiri dari tiga kelompok, yaitu Bank Umum, Bank Syariah, dan Bank Perkreditan Rakyat. Dari tiga kelompok populasi ini, dipilih populasi industri bank umum, sedangkan Bank Syariah dan BPR tidak masuk dalam penelitian ini. Dari populasi bank umum, dipilih kelompok Bank Pembangunan Daerah.

Sampel adalah bagian dari populasi. Dalam penelitian ini, sampel penelitian adalah Bank Pembangunan Daerah yang merupakan bagian dari industri perbankan. Dengan demikian sampel penelitian adalah semua bank yang masuk dalam kelompok Bank Pembangunan Daerah periode 2008 sampai dengan tahun 2012.

Sumber data yang digunakan adalah data sekunder yang berasal dari laporan keuangan BPD tahunan 2008-2012. Sumber data lain adalah Direktori Perbankan Indonesia (Bank Indonesia, 2008-2012) untuk periode tahun 2008-2012. Sumber data ini akan diperoleh informasi tentang data inflasi dan pertumbuhan kredit masing-masing regional sesuai lokasi provinsi masing-masing BPD tersebut. 
Data Statistik Ekonomi dari BPS untuk mendapatkan data GDP regional (PDRB). Data PDRB yang diambil dalam tahunan. Sehingga nantinya dampak PDRB terhadap kinerja bank dengan pengukuran dalam tahunan. Sedangkan data makro dalam penelitian ini diambilkan dari data Statistik Perbankan Indonesia yang diterbitkan oleh Bank Indonesia.

Analisis data dalam penelitian ini dilakukan dengan menggunakan metode Ordinary Least Square dengan data panel. Analisis data panel digunakan karena data penelitian ini menggunakan urut waktu tahun 2008 sampai dengan tahun 2012 dan data cross section untuk semua BPD yang ada di Indonesia.

Dalam data panel, perlu diuji apakah model regresi data panelnya menggunakan fixed effect model (FEM) atau Random effect model (REM). Untuk itu diperlukan uji Hausman atas data panel tersebut. Uji ini menggunakan Ho: Model REM dan H1: model FEM. Bila P-value Hausment test menunjukkan di atas alpha 1 persen atau 5 persen atau 10 persen, maka Ho diterima, yaitu data panel tersebut sesuai untuk menggunakan model REM (Gujarati 2003).

Suatu model regresi dikatakan BLUE dan dapat digunakan sebagai dasar analisis data dan uji hipotesis apabila residual model tersebut terdistribusi secara normal dan model estimasi tidak memiliki gejala klasik seperti gejala Multicolinearitas, Heteroskedastisitas, dan Autokorelasi. Untuk itu dalam penelitian ini akan dilakukan uji normalitas dari setiap model estimasi yang dihasilkan dan uji gejala klasik sebelum model estimasi tersebut digunakan sebagai uji hipotesis yang telah disusun dalam bab 2 dalam penelitian ini.

Untuk melihat pengaruh independet variable terhadap dependent variable, maka digunakan analisis Regresi Linear berganda menggunakan OLS (Ordinary Least Square), dengan menggunakan persamaan penelitian di bawah ini.

$$
\begin{aligned}
& \mathrm{ROA}_{\text {it }}=\gamma_{0}+\gamma_{1} \mathrm{BOPO}_{\text {it }}+\gamma_{2} \mathrm{CAR}_{\mathrm{it}}+\gamma_{3} \mathrm{LNSIZE}_{\mathrm{it}}+\gamma_{4} \mathrm{GPDRB}_{\mathrm{t}-1, \mathrm{r}}+\gamma_{5} \mathrm{GCRED}_{\mathrm{t}, \mathrm{r}}+
\end{aligned}
$$

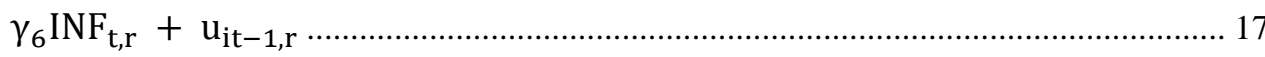

Lebih jauh masing-masng simbol variabel dalam persamaan penelitian tersebut adalah sebagai berikut: $R O A_{i t}$ adalah ROA bank i pada tahun t. $B O P O_{i t}$ adalah efisiensi bank i pada tahun t. $C A R_{i t}$ adalah CAR pada bank i pada waktu t. $L N S I Z E_{i t}$ adalah lonSIZE bank i pada tahun t. GPDRB $B_{t-1, r}$ adalah GPDRB tahun sebelumnya pada waktu t pada regional r. GCRED $D_{t, r}$ adalah pertumbuhan kredit pada regional $r$ pada waktu t. Terakhir dari simbol di atas, $I N F_{t, r}$ adalah inflasi pada waktu $\mathrm{t}$ pada regional $\mathrm{r}$.

Uji hipotesis akan dilakukan dengan melihat signifikansi koefisien dari independent variable dengan mengunakan ujit t (uji parsial) dan juga menggunakan uji pengaruh bersama-sama atau simultan, yaitu uji F. Dalam penelitian ini, uji hipotesis yang digunakan adalah uji t. Uji t digunakan untuk menguji hipotesis alternatif: 1). Ha1: Efisiensi bank diduga berpengaruh terhadap kinerja keuangan 
perbankan BPD; 2). Ha2: Kecukupan modal diduga berpengaruh terhadap kinerja keuangan BPD; 3). Ha3: Ukuran BPD diduga berpengaruh terhadap kinerja keuangan BPD; 4). Ha4: Pertumbuhan produk domestik regional tahun sebelumnya diduga berpengaruh terhadap kinerja keuangan bank BBD tahun sekarang; 5). Ha5: Pertumbuhan kredit perbankan regional diduga berpengaruh terhadap kinerja keuangan bank; dan 6). Ha6: Inflasi regional diduga berpengaruh terhadap kinerja keuangan bank.

\section{ANALISIS DAN PEMBAHASAN}

\section{Sampel penelitian}

Sampel penelitian ini terdiri dari seluruh BPD di Indonesia. BPD dimiliki oleh Pemda Provinsi Tk.1. Terdapat 33 provinsi di seluruh Indonesia. Dari 33 jumlah provinsi tersebut, jumlah BPD seluruh Indonesia adalah 26 bank, perbedaan ini karena 7 provinsi bergabung di antara BPD yang ada. Pada umumnya provinsi yang belum memiliki BPD sendiri adalah provinsi baru yang muncul sejak reformasi. Jumlah observasi dari 26 BPD untuk periode 2008-2012 adalah 130 observasi.

\section{Statistik Deskriptif}

Gambaran statistik deskriptif penelitian dapat dilihat pada Tabel 4 (Lampiran).

\section{Gambaran Efisiensi BPD di Indoensia Periode 2008-2012}

Rata-rata BOPO adalah 72,459 persen atau rata-rata beban operasi BPD selama periode pengamatan adalah 72,46 persen dari pendapatan operasinya. Nilai rata-rata BOPO ini di bawah nilai mediannya, yaitu 73,28 persen, sehingga sebagian besar BPD memiliki efisiensi di bawah median atau lebih baik. Nilai BOPO tertinggi (paling tidak efisien), yaitu 92,98 persen terdapat pada bank BACH (BPD Banda Aceh) tahun 2010. Sedangkan bank paling efisien dengan BOPO terendah, yaitu bank BSST (BPD Sulawesi Selatan) terjadi pada tahun 2008 dengan nilai 54,03 persen. Pada tahun 2008 BPD ini juga memperoleh kinerja terbaik dengan ROA tertinggi selama periode pengamatan. Gambaran rata-rata BOPO pertahun, BPK paling efisien dan tidak efisien setiap tahun pengamatan dapat dilihat pada Tabel 5.

Bank paling tidak efisien, yaitu bank dengan skor BOPO tertinggi di tahun pengamatannya. Pada Tabel 5 dan Gambar 2(Lampiran), terlihat bahwa Bank DKI (BDKI) mendapat predikat bank paling tidak efisien pada tahun 2008. BPD yang paling tidak efisien adalah BSTR (BPD Sumut) tahun 2009, BACH (Bank Aceh) tahun 2010, BSUA (BPD Sulawesi Utara) tahun 2011, dan BSSN (BPD Sumatera Selatan) tahun 2012. Dari kelima BPD paling tidak efisien ditahunnya, yang mendapat predikat paling tidak efisien selama lima periode pengamatan adalah bank BACH tahun 2010. 
Bank paling efisien setiap tahun adalah bank dengan skor BOPO paling rendah. Pada Tabel 5 dan Gambar 2 (Lampiran) terlihat ada satu BPD yang mendapat predikat bank paling efisien selama tiga tahun, yaitu BSTA (BPD Sulawesi Tenggara) pada tahun 2009, 2011, dan 2012. Sedangkan dua BPD lain yang mendapat predikat bank paling efisien, yaitu BSST (BPD Sulawesi Selatan) tahun 2008 dan BKTM (BPD Kaltim) tahun 2010.

Yang paling menarik dari hasil peringkat bank paling efisien di atas adalah tidak ada satu pun BPD di pulau jawa yang notebene memiliki total aset lebih besar dibandingkan BPD di luar jawa mendapatkan predikat BPD paling efisien. Hal ini menujukkan bahwa aset BPD yang besar tidak menjamin BPD tersebut lebih efisien dibandingkan dengan BPD dengan aset yang rendah.

\section{Hasil Persamaan Regresi}

Hasil uji Hausman (Tabel 6 pada Lampiran) menunjukan bahwa model yang digunakan untuk pendekatan data panel adalah random effect model. Hasil regresi persamaan penelitian menggunakan bantuan statistic software dapat dilihat pada Tabel 7 (Lampiran).

Persaman regresi dari observasi penelitian dapat ditulis sebagai berikut:

$$
\begin{aligned}
R O A_{i t}= & 0.154080-0.100035 \text { BOPO }_{i t}-0.038844 C A R_{i t}-0.002358 \text { LNSIZE }_{i t}- \\
& 0.015448 G P D R B_{t-1, r}-0.014209 G C R E D_{t, r}+0.048321 I N F R_{t, r} \ldots \ldots \ldots \ldots \ldots \ldots . .18
\end{aligned}
$$

Hasil regresi di atas memiliki adjusted $r$ square adalah 58,30 persen. Variabel bebas penelitian mempunyai kemampuan menjelaskan variasi variabel ROA sebesar 58,30 persen. Sisanya dijelaskan oleh vaiabel lain yang tidak masuk dalam penelitian ini.

Sebelum diinterpretasikan dan digunakan untuk uji hipotesis, hasil regresi persamaan penelitian di atas akan dilakukan uji normalitas residual dan uji klasik. Berikut dijelaskan uji normalitas residual persamaan regresi, uji gejala klasik, dan interpretasi hasil persamaan regresi penelitian.

\section{Uji Normalitas Residual dan Uji Gejala Klasik}

Hasil uji normalitas residual menggunakan Jarque-bera test menunjukkan bahwa probabilitas Jarque-Bera 0.22038 tidak signifikan pada alpha 5 persen sehingga distribusi residual persamaan regresi adalah normal. Dengan distribusi normal dari residual persamaannya, maka hasil regesi telah memenuhi salah satu syarat dikatakan BLUE.

Hasil uji multikolinearitas menunjukkan bahwa korelasi antar variabel independen paling tinggi adalah -0,4285, dengan demikian tidak ada gejala multikolinearitas pada hasil regresi di atas (lihat Tabel 8 pada Lampiran). Tidak adanya korelasi antar independen pada hasil persamaan regresi penelitian ini, maka hasil regresi telah memenuhi salah satu syarat dikatakan BLUE. 
Hasil uji Durbin-Watson (lihat Tabel 7 pada Lampiran) menunjukkan bahwa DW statistic adalah 1.947914. Nilai DW statistic berada di antara nilai Du dan di bawah nilai 4-Du. Nilai DU dan 4-Du dengan k=6 dan sampel 130 adalah 1,836 dan 2,164. Dengan demikian persamaan regresi di atas tidak terdapat gejala otokorelasi.

Uji heteroskedastisitas menggunakan Breusch-Pagan-Godfrey. Hasil uji dengan menggunakan Breusch-Pagan-Godfrey ini menunjukkan bahwa persamaan regresi ini tidak terdapat gejala heteroskedastisitas. Artinya residual persamaan regresi tidak berkorelasi dengan variabel independen persamaan regresi. Hal ini dapat dilihat pada Tabel 9 (Lampiran).

Hasil uji gejala klasik di atas menunjukkan tidak adanya gejala klasik dan residual terdistribusi normal dari hasil regresi penelitian ini. Dengan demikian, maka hasil persamaan regresi penelitian ini sudah BLUE sehingga dapat digunakan untuk dasar uji hipotesis alternatif 1 sampai dengan 6.

\section{Hasil Uji Hipotesis}

Berdasarkan Tabel 7 (Lampiran) maka pengujian hipotesis menunjukan bahwa: 1). Hipotesis Ha1, efisiensi bank (BOPO) berpengaruh terhadap kinerja (ROA) BPD dapat diterima; 2). Hipotesis Ha2, kecukupan modal (CAR) bank dapat mempengaruhi kinerja keuangan (ROA) bank, dapat diterima; 3). Ha3, ukuran bank signifikan mempengaruhi kinerja bank dapat diterima; 4). Ha4, tingkat pertumbuhan PDRB dapat mempengaruhi kinerja keuangan BPD tidak dapat diterima; 5). Ha5, tingkat pertumbuhan PDRB signifikan mempengaruhi negatif kinerja BPD dapat diterima; dan 6). Ha6, tingkat inflasi regional dapat mempengaruhi kinerja BPD dapat diterima.

\section{Analisis Pengaruh BOPO terhadap Kinerja Keuangan BPD}

Hasil regresi dan uji hipotesis di atas menunjukan bahwa ketidakefisienan BPD dapat mempengaruhi negatif kinerja BPD. Semakin tidak efisien suatu bank, maka kinerja bank tersebut akan semakin turun (Sounders \& Cornett 2011). Hasil ini sesuai dengan hasil studi Sudiyatno dan Suroso (2010), dan Sudiyatno dan Setyowati (2012). Semua penelitian tersebut menujukan pengaruh negatif BOPO terhadap kinerja keuangan (ROA). Dengan demikian hasil penelitian ini memperkuat temuan hasil-hasil penelitian sebelumnya.

\section{Analisis Pengaruh Kecukupan Modal terhadap Kinerja Keuangan BPD}

Kecukupan modal BPD mempengaruhi negatif terhadap kinerja BPD tersebut. Semakin tinggi kecukupan modal BPD, maka kinerja bank semakin turun. Hal ini menunjukkan bahwa indikasi kecukupan modal yang tinggi disebabkan dua hal, yaitu modal bank yang tinggi atau ATMR BPD tinggi. Bank-bank cenderung melakukan investasi dan pemberian kredit yang berisiko tinggi untuk imbal hasil tinggi (Hull 2016). Kebijakan bank cenderung melakukan ambil risiko menyebabkan ATMR bank meningkat sehingga kecukupan modalnya menurun. Bank yang 
mengurangi ambil risiko sehingga ATMR-nya menurun akan menyebabkan kecukupan modal bank meningkat sehingga keuntungan yang diperoleh juga mengalami penurunan akhirnya menyebabkan kinerja bank mengalami penurunan (Rose \& Hudgins 2005).

Hasil penelitian ini mendukung hasil penelitian Sudiyatno dan Suroso (2010) menunjukkan adanya pengaruh negatif signifikan kecukupan modal terhadap kinerja bank. Hasil penelitian Berger dan Bouwman (2009) menunjuk hasil yang konsisten dengan penelitian ini, yaitu permodalan bank mempunyai pengaruh negatif terhadap kinerja bank besar dan menengah selama krisis keuangan. Hasil penelitian ini tidak mendukung hasil penelitian Sudiyatno dan Setyowati (2012) dan teori yang diungkapan oleh (Rose 2002), yaitu tingkat kecukupan modal yang tinggi akan memberikan kesempatan diversifikasi aset bagi bank dan dapat melakukan ekspansi sehingga dapat meningkatkan kemampuan profitabilitas bank atau kinerja keuangan bank.

\section{Analisis Pengaruh Ukuran Bank terhadap Kinerja Keuangan BPD}

Hasil empiris penelitian ini menunjukkan bahwa semakin tinggi ukuran BPD, maka semakin turun kinerja bank tersebut. Selama periode pengamatan tahun 2008 sampai dengan. 2012, menunjukan bahwa BPD dengan aset tinggi memiliki kinerja keuangan lebih rendah dibandingkan dengan BPD dengan aset yang lebih rendah.

Hasil empiris ini sesuai dengan hasil penelitian sebelumnya yang dilakukan oleh Bonin et al. (2003). Hasil empiris ini tidak mendukung teori yang dikemukakan oleh Subramanyam dan Wild (2009) yaitu total aset mempunyai hubungan negatif terhadap ROA atau kinerja perusahaan dengan asumsi apabila aset meningkat, NIAT dan sales tidak berubah. Tidak didukungnya teori yang diungkapkan oleh Subramanyam dan Wild (2009) karena asumsi yang diajukan tidak sesuai hasil empiris.

\section{Analisis Pengaruh Indikator Ekonomi Daerah terhadap Kinerja Keuangan BPD}

Hasil penelitian ini menunjukan bahwa dari ketiga indikator ekonomi regional hanya pertumbuhan PDRB tahun sebelumnya menunjukkan hasil tidak signifikan mempengaruhi kinerja keuangan BPD tahun sekarang. Sedangkan indikator pertumbuhan kredit perbankan regional dan tingkat inflasi regional signifikan mempengaruhi kinerja BPD.

Hasil ini tidak konsisten dengan hasil penelitian yang dilakukan oleh Bonin et al. (2003) dan Iannotta et al. (2006) yang menemukan bahwa pertumbuhan GDP signifikan positif mempengaruhi kinerja bank. Hasil ini juga tidak konsisten dengan teori yang diungkapkan oleh Rose dan Hudgins (2005) yang menyatakan bahwa pertumbuhan gross domestic bruto tahun sebelumnya dapat mempengaruhi kinerja keuangan bank tahun sekarang. Hal ini pertama, karena dampak pengaruh 
pertumbuhan ekonomi tahun sekarang baru dirasakan pada kinerja perusahaan tahun berikutnya. Tidak konsistennya hasil penelitian ini dengan penelitian sebelumnya disebabkan karena pertumbuhan ekonomi yang digunakan adalah regional (provinsi) sedangkan penelitian yang dilakukan sebelumnya menggunakan pertumbuhan ekonomi nasional suatau negara. Kedua, dominasi BPD di daerahnya dalam penyaluran kredit dan penyerapan dana masyarakat masih kalah dengan perbankan nasional yang mempunyai aset dan jaringan cabang yang lebih luas dibandingkan BPD. Ketiga, kualitas SDM BPD diperkirakan masih rendah dibandingkan dengan kualitas SDM dari perbankan nasional. Keempat, diduga tingkat efisiensi bank nasional yang mempunyai cabang di setiap provinsi lebih tinggi dibandingkan dengan BPD. Dengan kondisi ini, kenaikan pertumbuhan ekonomi di provinsi tersebut tidak dapat mempengaruhi kinerja BPD karena tidak mampu bersaing dengan bank nasional. BPD lebih mengandalkan pemberian kredit kepada perusahanperusahan daerah terutama yang dimiliki oleh pemerintah daerah setempat. Begitu juga sumber dananya diduga lebih mengantungkan dari dana PAD dan proyekproyek pemerintah setempat.

Pertumbuhan kredit regional (semua perbankan di daerah setempat) signifikan negatif mempengaruhi kinerja keuangan BPD. Hasil ini tidak sesuai dengan teori yang diungkapkan oleh Rose dan Hudgins (2005) yang menyatakan bahwa kenaikan pertumbuhan kredit dapat meningkatkan kinerja keuangan perusahan. Hal ini disebabkan berbagai faktor, misalnya kemampuan SDM. Peningkatan pertumbuhan kredit tidak mampu dikelola dengan baik karena rendahnya kualitas SDM. Hal ini perlu kajian lebih dalam pada penelitian berikutnya.

Dari data observasi menunjukkan bahwa pertumbuhan kredit dari tahun 2008 sampai dengan 2012 cenderung meningkat secara rata-rata. Peningkatan pertumbuhan kredit regional ini tidak serta-merta meningkatkan kinerja BPD. Hal ini karena pangsa kredit di provinsi diduga belum dikuasi oleh BPD setempat tetapi dikuasai bank nasional besar yang mempunyai cabang di daerah setempat. Hal ini, pertama, diduga BPD tidak menggunakan momen untuk meningkatkan kinerjanya terkait dengan peningkatan pertumbuhan kredit, bank dapat meningkatkan pendapatan operasinya. Kedua, diduga BPD mendapatkan pertumbuhan kredit naik setiap tahun selama periode observasi, tetapi tidak didukung oleh sarana dan kesiapan SDM untuk memanfaatkan kenaikan pertumbuhan kredit untuk meningkatkan kinerjanya.

Hasil penelitian ini menunjukan bahwa tingkat inflasi secara signifikan meningkatkan kinerja BPD. Hasil ini sesuai teori yang diungkapkan oleh Rose dan Hudgins (2005) menyatakan bahwa nominal suku bunga pinjaman bank sudah memasukkan inflasi. Suku bunga real adalah suku bunga dikurangi dengan tingkat inflasi. Semakin tinggi inflasi, maka semakin tinggi tingkat suku bunga. Tingginya suku bunga akan mempengaruhi kinerja perbankan (Subramanyam \& Wild 2009). Semakin tinggi inflasi, maka tingkat kinerja keuangan bank akan bisa semakin 
rendah atau tinggi (Pindyck \& Rubinfeld 1995). Kenaikan tingkat inflasi dapat berdampak negatif atau positif terhadap kinerja keuangan bank.

\section{Implikasi Manajerial Hasil Penelitian}

Tingkat ketidakefisienan BPD, kecukupan modal, ukuran bank, dan pertumbuhan kredit mempengaruhi negatif signifikan terhadap kinerja BPD. Hasil ini memberikan implikasi kepada manajer BPD dalam membuat program peningkatan kinerja keuangan banknya. Pertama, manajer bank harus melakukan penurunan rasio BOPO agar tingkat efisiensi bank naik sehingga kinerja bank menguat. Kedua, manajer bank harus melakukan pengaturan kecukupan modal sesuai dengan ketentuan otoritas perbankan bahwa CAR ninimal 8 persen. Jumlah kecukupan modal (CAR) jauh di atas ketentuan tersebut akan membawa implikasi turunnya kinerja BPD tersebut. Ketiga, kenaikan ukuran BPD harus diiringi dengan kenaikan efisiensi operasional bank dan peningkatan volume operasional bank agar kenaikan ukuran BPD tidak menyebabkan penurunan kinerja bank. Keempat, manajer bank harus melakukan peningkatan kualitas SDM-nya dalam pengelolaan kredit agar momen pertumbuhan kredit perbankan di provinsi tersebut dapat dimanfaatkan dengan peningkatan kredit BPD. Implikasi terkait dengan pertumbuhan kredit adalah manajemen perlu membuat program peningkatan efisiensi pengelolaan kredit BPD, peningkatan pemberian kredit kepada masyarakat dan perusahaan swasta untuk meningkatkan pertumbuhan ekonomi dan kinerja BPD tersebut.

Pengaruh positif tingkat inflasi regional provinsi terhadap kinerja BPD setempat membawa implikasi kepada manajerial BPD, yaitu kenaikan inflasi di daerah yang berdampak pada kenaikan suku bunga sehingga BPD harus meningkatkan program ekspansi kreditnya. Hal ini dilakukan sepanjang kualitas sumber daya manusia pada BPD sudah ditingkatkan dengan baik sehingga mampu mengelola debitur yang prospektif. Apabila tidak mampu meningkatkan kualitas sumber daya manusia, maka pencarian debitur prospektif dan pengelolaannya menjadi sulit. Satu hal yang membedakan operasional BPD dengan bank komersial lainnya adalah sebagian besar debitur kredit BPD adalah para pegawai negeri di daerah terutama lingkungan pemerintah daerah, sehingga dengan tingkat bunga naik dapat meningkatkan pendapatan BPD. Sehingga masalah utamanya ada pada kualitas sumber dayanya bukan dari sisi debitur kreditnya.

\section{SIMPULAN, KETERBATASAN DAN SARAN}

Rata-rata BOPO BPD di Indonesia selama periode lima tahun pengamatan adalah 72,45 persen. BPD Aceh mendapat predikat bank paling tidak efisien dengan BOPO 92,98 persen dan BPD Sulawesi Selatan mendapat predikat BPD paling efisien dengan BOPO 54,03 persen. BPD paling efisien per tahun masing-masing 2008, 2009, 2010, 2011, dan 2012 berturut-turut adalah BDKI, BSTR, BACH, BSUA, dan BSSN. Sedangkan BPD paling tidak efisien per tahun masing-masing 
2008, 2009, 2010, 2011, dan 2012 berturut-turut adalah BSST, BSTA, BKTM, BSTA, dan BSTA.

Tingkat ketidakefisienan BPD, kecukupan modal BPD, ukuran BPD, dan pertumbuhan kredit regional mempunyai pengaruh negatif terhadap kinerja keuangan BPD. Pertumbuhan PDRB dimana BPD tersebut berada tidak mempunyai pengaruh signifikan terhadap kinerja keuangan BPD di Indonesia. Tingkat inflasi regional berpengaruh positif terhadap kinerja BPD di Indonesia.

Keterbatasan penelitian ini, yaitu 1). Tidak meneliti faktor pemicu yang menyebabkan pertumbuhan PDRB tidak berpengaruh terhadap kinerja BPD di Indonesia; 2). Tidak meneliti lebih jauh faktor pemicu kenapa pertumbuhan kredit regional tidak berdampak positif pada kinerja BPD di Indonesia; dan 3). Menggunakan pendekatan tradisional dalam mengukur efisiensi BPD. Kelemahan pendekatan ini adalah tingkat efisiensi suatu BPD dengan BPD lain tidak dapat dibandingkan dengan baik.

Saran penelitian ini, yaitu 1). Untuk meningkatkan kinerja BPD, manajer BPD harus membuat program penguatan kinerja keuangan melalui peningkatan efisiensi bank, pengelolaan tingkat kecukupan modal, kenaikan aset bank harus diiringi dengan kenaikan efisiensi operasional, peningkatan volume operasional, dan peningkatan kualitas SDM dalam pengelolaan kredit bank; 2). Bagi peneliti berikutnya agar menghitung tingkat efisiensi bank menggunakan pendekatan frontier. Dengan pendekatan ini, tingkat efisiensi bank dapat dibandingkan dengan bank lain, sehingga dapat dinilai peringkat efisiensi bank dengan baik; 3). Bagi peneliti berikutnya agar meneliti faktor-faktor pemicu yang menyebabkan dampak pertumbuhan kredit negatif terhadap kinerja keuangan BPD, yaitu kualitas SDM, sistem monitoring kredit, diversifikasi pemberian kredit, dan faktor pemicu lainnya yang menpunyai hubungan kuat terhadap pertumbuhan kredit dengan kinerja keuangan yang baik; 4). Bagi penelitian berikutnya disarankan untuk melakukan penelitian terkait dengan faktor-faktor pemicu yang menyebabkan pertumbuhan PDRB tidak signifikan mempengaruhi kinerja BPD di Indonesia, yaitu antara lain kualitas SDM, diversifikasi pemberian kredit, kemampuan kompetensi dengan bank lain, dan faktor-faktor potensi dana murah lainnya yang dapat meningkatkan kinerja perbankan pada saat PDRB mengalami pertumbuhan; dan 5). Bagi lembaga otoritas perbankan, disarankan untuk melakukan program penguatan efisiensi BPD di Indonesia untuk meningkatkan kinerja keuangan BPD sehingga berkontribusi dalam sistem keuangan perbankan dan memberikan penguatan persyaratan kompetensi bagi pejabat BPD khususnya pejabat pemberi kredit dan monitoring kredit.

\section{DAFTAR PUSTAKA}

Alfarisi, A. S. 2008. "Analysis terhadap laba, profit efficiency, dan agency cost hypothesis pada Bank Syariah dan Bank Umum di Indonesia." Fakultas 
Ekonomi Universitas Padjajaran Bandung.

Bank_Indonesia. 2008. "Statistik perbankan Indonesia tahun 2008." 2011. "Statistik perbankan Indonesia bulanan 10 (54) April 2011."

Beck, Thorsten, dan Heiko Hesse. 2006. "Bank efficiency, ownership, and market structure: why are interest spreads so high in Uganda." World Bank Policy Research Working Paper. https://doi.org/10.1596/1813-9450-4027.

Berger, Allen N., dan Christa H.S. Bouwman. 2009. "Bank capital, survival, and performance around financial crises."

Berger, Allen N., dan David B. Humphrey. 1997. "Efficiency of financial institutions: International survey and directions for future research." Forthcoming in European Journal of Operational Research. https://doi.org/10.1016/S0377-2217(96)00342-6.

Bonin, John P., Iftekhar Hasan, dan Paul Wachtel. 2003. "Bank performance, efficiency and ownership in transition countries." In Proceedings of The Ninth Dubrovnik Economic Conference The 9 DEC., 29:31-53. Journal of Banking and Finance. https://doi.org/10.1016/j.jbankfin.2004.06.015.

Carbo, S, Gardener E. P. M, dan J.William. 1999. "Efficiency and technical change in the European saving bank sector." In Proceedings of the annual seminar of the European Association of University Teachers of Banking and Finance. Lisbhon, 2-3 September 1999.

Chen, Y.-K. 2001. "Three essays on bank efficiency." Doctor of Philosophy to the Faculty of Drexel University.

Endri. 2008. "Efisiensi teknis perbankan syariah di Indonesia." Finance and Banking Journal 10 (2): 123-40.

Farel, M. J. 1957. "The measurement of productivity efficiency." Journal of Royal Statistical Society 120 (3): 253-90.

Fiordelisi, Franco, dan Phil Ibanez, Marques David; Molyneux. 2010. "Effeiciency and risk in European banking." Working paper series 1211.

Fiorentino, Elisabetta, Alexander Karmann, dan Michael Koetter. 2006. "The cost efficiency of German banks: A comparison of SFA and DEA." Deutsche Bundesbank Euro System-Discussion. Working paper Serie 2: Banking and Financial Studies 10.

Fraser, Lyn M., dan Aileen Ormiston. 2007. Understanding financial statament. Eight edit. New Jersey: Prentice Hall.

Girardone, Claudia, Philip Molyneux, dan Edward P. M. Gardener. 2004. "Analysing the determinants of bank efficiency: The case of Italian banks." Applied Economics 36 (3): 215-27. 
Gujarati, Damodar N. 2003. Basic econometric. Fourth Edi. New York: Mc GrawHill.

Hartono, Edy. 2009. "Analisis efisiensi biaya industri perbankan Indonesia dengan menggunakan metode parametrik stochastik frontier analysis (studi pada perbankan yang terdaftar di Bursa Efek Indonesia)." Magister Manajemen Fakultas Ekonomi Universitas Airlangga.

Hull, John C. 2016. Risk management and financial institution. Fourth Edi. New Jersey: John Wiley and Sons.

Iannotta, G, G Nocera, dan A Sironi. 2006. "Ownership structure, risk and performance in the European banking industry." Journal of Banking \& Finance. $\quad$ Vol. $31 . \quad$ Working paper. https://doi.org/10.1016/j.jbankfin.2006.07.013.

Magalhaes, Romulo, Gutiérrez Urtiaga, María, dan Josep A. Tribo. 2010. “Banks' ownership structure, risk and performance," 1-42.

Mardanugraha, Eugenia. 2005. "Efisiensi perbankan di Indonesia dipelajari melalui pendekatan fungsi biaya parametric." Program Studi Ilmu Ekonomi Pasca Sarjana Fakultas Ekonomi Universitas Indonesia.

Mester, Loretta J. 1993. "Efficiency of banks in the third federal reserve district." 94-13. made possible by a generous grant from the Alfred P. Sloan Foundation.

Micco, Alejandro, Ugo Panizza, dan Monica Yanez. 2005. "Bank ownership and performance - does politics matter?” Journal of Banking and Finance 31 (1): 219-41. https://doi.org/10.1016/j.jbankfin.2006.02.007.

Mirnawati, Fadliah. 2007. "Analisis efisiensi perbankan sebelum dan sesudah menjadi bank listed dengan menggunakan analisis non parametric." Program Studi Ilmu Manajemen Pascasarjana Fakultas Ekonomi Universitas Indonesia.

Nigmonov, A. 2010. "Bank performance and efficiency in Uzbekistan." Eurasian Journal of Business and Economics 2 (5): 1-25.

Pastor, JoséManuel, Francisco Ferez, dan Javier Quesada. 1997. "Efficiency analysis in banking firms: An international comparison." European Journal of Operational Research 98: 395-407. https://doi.org/10.1016/S03772217(96)00355-4.

Peter S. Rose, dan Sylvia C. Hudgins. 2005. Bank management and financial service. Sixth edit. Singapore: Mc Graw-Hill.

Pindyck, Robert S., dan Daniel L. Rubinfeld. 1995. Microeconomic. Third Edit. China: Prentice-Hall. 
Robinson, Thomas R., Mary M. Munter, dan Julia Grant. 2004. Financial statement analysis: a global perspective. Internatio. New Jersey: Pearson Education International.

Rose, Peter S. 2002. Commercial bank management. Internatio. New York: McGraw-Hill.

Sounders, Anthony, dan Marcia Millon Cornett. 2011. Financial institution management: A risk management approach. Seventh ed. New York: McGraw-Hill.

Subramanyam, K.R., dan John J. Wild. 2009. Financial statement analysis. Tenth edit. Singapore: McGraw-Hill.

Sudiyatno, B., dan R. Setyowati. 2012. "Pengaruh BOPO, NPL, NIM dan CAR terhadap kinerja keuangan bank (studi pada bank-bank yang listed di bursa efek Indonesia)." Dinamika Akuntansi, Keuangan dan Perbankan 2 (2): 5773.

Sudiyatno, Bambang, dan Jati Suroso. 2010. “Analisis pengaruh DPK, BOPO, CAR dan LDR terhadap kinerja keuangan pada sektor perbankan yang go public di Bursa Efek Indonesia (BEI)." Dinamika Keuangan dan Perbankan. https://doi.org/10.7202/1005434ar.

White, Gerald I., Ashwinpaul C. Sondhi, dan Dov Fried. 2003. The analysis and uses of financial statement. Third edition, United Statesof America: Jhon Willey. Third esit. United States of America: Jhon Willey. 


\section{LAMPIRAN}

Tabel 1

Posisi Penghimpunan Dana dan Penyaluran Dana Bank Umum

Per 31 Desember 2001 - Oktober 2010

(Rp.Triliun)

\begin{tabular}{|c|c|c|c|c|c|c|c|c|c|c|}
\hline Indikator & 2001 & 2002 & 2003 & 2004 & 2005 & 2006 & 2007 & 2008 & 2009 & 2010 \\
\hline \multicolumn{11}{|c|}{ Penghimpunan dana } \\
\hline \multicolumn{11}{|l|}{ Rupiah: } \\
\hline - Giro & 120,0 & 130.2 & 150.1 & 171.0 & 193.9 & 249.6 & 309.3 & 307.7 & 332.7 & 342.8 \\
\hline - Deposito & 344.9 & 364.4 & 351.8 & 351.9 & 455.0 & 510.0 & 541.0 & 676.0 & 758.3 & 905.6 \\
\hline - Tabungan & 171.3 & 192.6 & 240.7 & 296.8 & 281.3 & 333.9 & 434.5 & 476.7 & 565.6 & 728.8 \\
\hline \multicolumn{11}{|l|}{ Valas } \\
\hline - Giro & 66.2 & 66.8 & 69.8 & 74.9 & 87.5 & 88.5 & 96.2 & 122.3 & 133.2 & 138.7 \\
\hline - Deposito & 95.1 & 81.6 & 77.0 & 69.6 & 110.0 & 105.2 & 125.7 & 148.7 & 143.4 & 138.2 \\
\hline - Tabungan & - & - & - & & 0.2 & 0.6 & 4.1 & 21.9 & 39.4 & - \\
\hline Jumlah DPK & 797.5 & 835.6 & 889.4 & 964.2 & 1.127 .9 & $1.287,8$ & $1.510,8$ & $1.753,3$ & $1.973,0$ & $2.254,1$ \\
\hline \multicolumn{11}{|l|}{$\begin{array}{l}\text { Penyaluran } \\
\text { Dana }\end{array}$} \\
\hline $\begin{array}{l}\text { Kredit } \\
\text { rupiah }\end{array}$ & 208,2 & 268,5 & 330,6 & 431,6 & 565,9 & 638,5 & 791,6 & $1.054,3$ & $1.228,7$ & $1.481,9$ \\
\hline $\begin{array}{l}\text { - Kredit } \\
\text { Valas }\end{array}$ & 112,7 & 102,6 & 104,5 & 127,8 & 129,8 & 153,8 & 210,4 & 253,4 & 209,3 & 261,2 \\
\hline $\begin{array}{l}\text { Jumlah } \\
\text { Penyaluran }\end{array}$ & 320,9 & 371,1 & 435,1 & 559,4 & 695,7 & 792,3 & $1.002,0$ & $1.307,7$ & $1.437,9$ & $1.743,1$ \\
\hline
\end{tabular}

Tabel 2

Kinerja Bank Umum di Indonesia

Periode 2001 - 2011

\begin{tabular}{|c|c|c|c|c|c|c|c|c|c|c|c|}
\hline Indikator & 2001 & 2002 & 2003 & 2004 & 2005 & 2006 & 2007 & 2008 & 2009 & 2010 & 2011 \\
\hline $\begin{array}{c}\text { Total aset } \\
\text { (triliun) }\end{array}$ & $1.099,7$ & $1.117,2$ & $1.213,5$ & $1.272,1$ & $1.469,8$ & $1.693,9$ & $1.986,5$ & $2.310,6$ & $2.534,1$ & $3.008,9$ & $3.652,0$ \\
\hline $\begin{array}{l}\text { DPK } \\
\quad \text { (triliun } \\
\text { rupiah) }\end{array}$ & 797,4 & 835,8 & 888,6 & 963,1 & $1.127,9$ & $1.287,1$ & $1.510,8$ & $1.753,3$ & $1.973,0$ & $2.338,8$ & $2.784,8$ \\
\hline $\begin{array}{l}\text { Kredit } \\
\text { (triliun } \\
\text { rupiah) }\end{array}$ & 316,1 & 371,1 & 440,5 & 559,5 & 695,6 & 792,3 & $1.002,0$ & $1.307,7$ & $1.437,9$ & $1.765,8$ & $2.199,1$ \\
\hline CAR (\%) & 19,9 & 22,4 & 19,4 & 19,4 & 19,3 & 21,3 & 19,3 & 16,8 & 17,4 & 17,2 & 16,1 \\
\hline $\begin{array}{l}\text { Gross } \\
\text { NPL }(\%)\end{array}$ & 12,2 & 7,5 & 6,8 & 4,5 & 7,6 & 6,1 & 4,1 & 3,2 & 3,3 & 2,6 & 2,2 \\
\hline $\operatorname{ROA}(\%)$ & 1,5 & 2,0 & 2,6 & 3,5 & 2,6 & 2,6 & 2,8 & 2,3 & 2,6 & 2,9 & 3,0 \\
\hline NIM (\%) & 3,6 & 4,1 & 4,6 & 6,4 & 5,6 & 5,8 & 5,7 & 5,7 & 5,6 & 5,7 & 5,9 \\
\hline $\begin{array}{l}\text { BOPO } \\
(\%)\end{array}$ & 98,4 & 94,8 & 88,1 & 76,6 & 89,5 & 87,0 & 84,1 & 88,6 & 86,6 & 86,1 & 85,4 \\
\hline LDR (\%) & 39,6 & 44,4 & 49,6 & 58,1 & 61,7 & 61,7 & 66,3 & 74,6 & 72,9 & 75,5 & 79,0 \\
\hline $\begin{array}{l}\text { Jumlah } \\
\text { Bank }\end{array}$ & 145,0 & 141,0 & 138,0 & 134,0 & 131,0 & 131,0 & 130,0 & 124,0 & 121,0 & 122,0 & 120,0 \\
\hline
\end{tabular}

Sumber: Bank Indonesia 
Tabel 3

Definisi dan Operasiobal Variabel Penelitian

\begin{tabular}{|c|c|c|c|c|}
\hline Variabel & Definsi & Indikator & Ukuran & Skala \\
\hline BOPO & $\begin{array}{l}\text { Beban operasional } \\
\text { terhadap pendapatan } \\
\text { operasional. }\end{array}$ & $\begin{array}{l}\text { Beban } \\
\text { operasional/pendapatan } \\
\text { operasional }\end{array}$ & rasio & rasio \\
\hline CAR & Capital Adequate ratio & $\frac{\text { total Modal }}{A T M R}$ & rasio & rasio \\
\hline GPDRB & $\begin{array}{l}\text { Growth Product Domestik } \\
\text { RegionalBruto }\end{array}$ & $\frac{P D R B_{t 1}-P D R B_{t 0}}{P D R B_{t o}}$ & rupiah & rasio \\
\hline LNSIZE & Total aset & Ln of asset & rasio & rasio \\
\hline GCRED & $\begin{array}{l}\text { Growth of credit yang } \\
\text { diberikan.dari perbankan } \\
\text { nasional. }\end{array}$ & {$\left[\frac{C R E D_{t 1}-C R E D_{t 0}}{C R E D_{t 0}}\right]$} & rasio & rasio \\
\hline INF & Tingkat inflasi & tahunan & rasio & rasio \\
\hline ROA & Return on Asset bank & $\frac{\text { Net Income after tax }}{\text { total asset }}$ & rasio & rasio \\
\hline
\end{tabular}

DAFTAR NAMA dan KODE BANK PEMBANGUNAN DAERAH

\begin{tabular}{rll} 
No & Nama Bank Pembanguan Daerah & Kode \\
\hline 1 & BPD Yogjakarta & BYTA \\
2 & PT BPD DKI & BDKI \\
3 & PT BPD Jawa Barat & BJBT \\
4 & PT BPD Nusa Tenggara Barat & BNTB \\
5 & PT BPD Jawa Tengah & BJTH \\
6 & PT BPD Jawa Timur & BJTR \\
7 & PT BPD Nusa Tenggara Timur & BNTT \\
8 & PT BBD Maluku & BMKU \\
9 & BBD Papua & BPPA \\
10 & PT BBD Bengkulu & BBLU \\
11 & PT BPD Sulawesi Tengah & BSTH \\
12 & PT BPD Sulawesi Tenggara & BSTA \\
13 & BPD Bali & BBLI \\
14 & PT BPD KALTENG & BKTG \\
15 & PT BPD Kaltim & BKTM \\
16 & PT BPD Kalimantan Barat & BKBT \\
17 & PT BPD Kalimantan Selatan & BKSN \\
18 & PT BPD Lampung & BLPG \\
19 & PT BPD Sumatera Selatan & BSSN \\
20 & PT BPD RIAU & BRAU \\
21 & BPD Sumatera Barat & BSBT \\
22 & PT BPD Sumatera Utara & BSTR \\
23 & PT BPD Aceh & BACH \\
24 & PT BPD Sulawesi Utara & BSUA \\
25 & BBPD Jambi & BJBI \\
26 & BPD Sulawesi Selatan & BSST \\
\hline & &
\end{tabular}




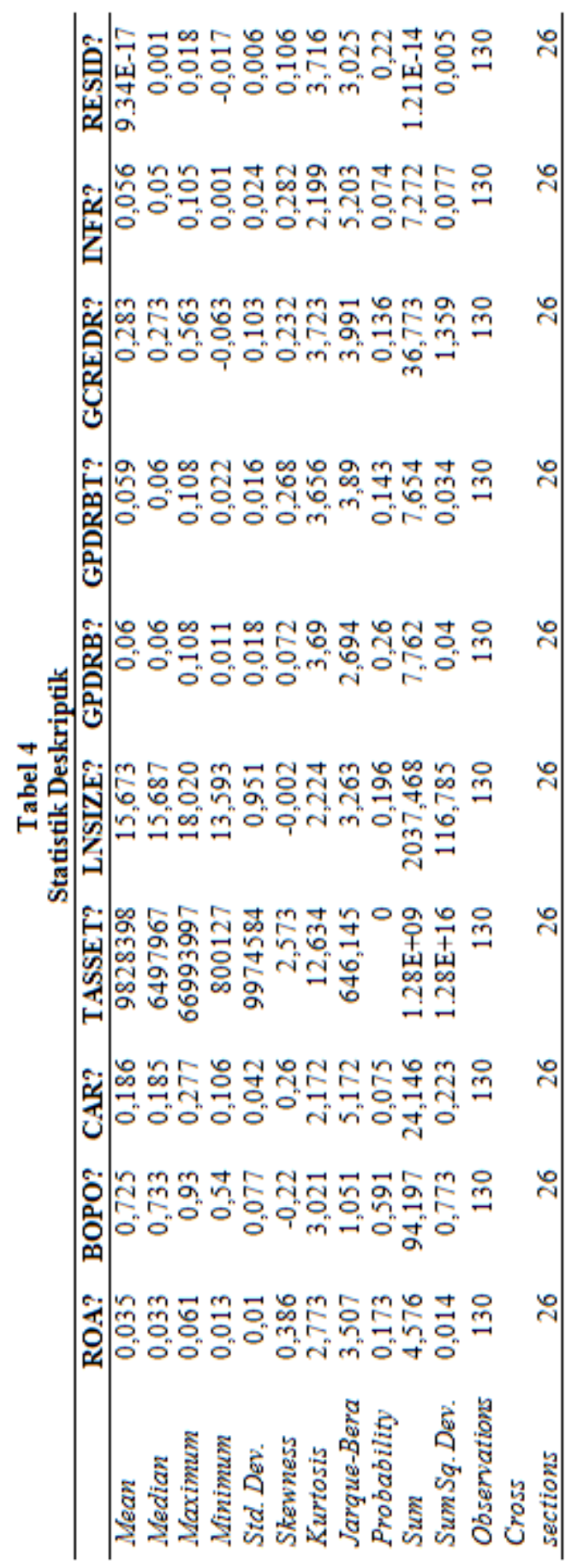


Tabel 5

Rata-rata BOPO Tahunan, Max dan Min BOPO

Periode 2008-2012

\begin{tabular}{lccccc}
\hline \multicolumn{1}{c}{ BPD } & $\mathbf{2 0 0 8}$ & $\mathbf{2 0 0 9}$ & $\mathbf{2 0 1 0}$ & $\mathbf{2 0 1 1}$ & $\mathbf{2 0 1 2}$ \\
\hline _BDKI & 0,897 & 0,885 & 0,83 & 0,797 & 0,814 \\
_BSTA & 0,795 & 0,556 & 0,648 & 0,545 & 0,596 \\
_BKTM & 0,553 & 0,637 & 0,553 & 0,639 & 0,682 \\
_BSSN & 0,818 & 0,781 & 0,808 & 0,806 & 0,823 \\
_BSTR & 0,74 & 0,898 & 0,687 & 0,76 & 0,778 \\
_BACH & 0,706 & 0,714 & 0,93 & 0,774 & 0,715 \\
_BSUA & 0,82 & 0,626 & 0,851 & 0,85 & 0,775 \\
_BSST & 0,54 & 0,571 & 0,66 & 0,72 & 0,717 \\
Rata-rata & 0,226 & 0,218 & 0,23 & 0,227 & 0,227 \\
Max & 0,897 & 0,898 & 0,93 & 0,85 & 0,823 \\
Min & 0,54 & 0,556 & 0,553 & 0,545 & 0,596 \\
Jumlah BPD & 26 & 26 & 26 & 26 & 26 \\
\hline
\end{tabular}

Tabel 6

Uji Housman

Correlated Random Effects - Hausman Test

Pool: APOOL

Test cross-section random effects

\begin{tabular}{|c|c|c|c|c|}
\hline \multicolumn{2}{|c|}{ Test Summary } & $\begin{array}{l}\text { Chi-Sq. } \\
\text { Statistic }\end{array}$ & Chi-Sq. d.f. & \multirow{2}{*}{$\begin{array}{l}\text { Prob. } \\
0.8840\end{array}$} \\
\hline Cross-section random & & 2.358054 & 6 & \\
\hline \multicolumn{5}{|c|}{ Cross-section random effects test comparisons: } \\
\hline Variable & Fixed & Random & $\operatorname{Var}($ Diff. $)$ & Prob. \\
\hline BOPO? & $-0,095$ & $-0,1$ & 0 & 0,33 \\
\hline CAR? & $-0,037$ & $-0,039$ & 0 & 0,916 \\
\hline LNSIZE? & $-0,002$ & $-0,002$ & 0 & 0,995 \\
\hline GPDRBT? & $-0,02$ & $-0,015$ & 0,001 & 0,826 \\
\hline GCREDR? & $-0,015$ & $-0,014$ & 0 & 0,763 \\
\hline INFR? & 0,05 & 0,048 & 0 & 0,872 \\
\hline
\end{tabular}

Tabel 7

Hasil Regresi Data panel menggunakan Random Effect Model

\begin{tabular}{lrrrr}
\hline \multicolumn{1}{c}{ Variable } & Coefficient & t-Statistic & Prob. & Sign \\
\hline C & 0,154 & 7,982 & 0 & $*)$ \\
BOPO? & $-0,1$ & $-12,194$ & 0 & $*)$ \\
CAR? & $-0,039$ & $-2,017$ & 0,046 & $* *)$ \\
LNSIZE? & $-0,002$ & $-2,383$ & 0,019 & $* *)$ \\
GPDRBT? & $-0,015$ & $-0,381$ & 0,704 & \\
GCREDR? & -0.014209 & $-2,707$ & 0,008 & $*)$ \\
INFR? & 0,048 & 2,212 & 0,029 & $* *)$ \\
R-squared & 0,602 & Mean dependent var & & 0,017 \\
Adjusted $R$-squared & 0,583 & S.D. dependent var & & 0,008 \\
S.E. of regression & 0,005 & Sum squared resid & & 0,003 \\
F-statistic & 31,059 & Durbin-Watson stat & & 1,948 \\
Prob(F-statistic) & 0 & & & \\
\hline
\end{tabular}

*) sign pada alpha 1\%,**) sign pada alpha 5\% 
Tabel 8

Uji Multikolinearitas

\begin{tabular}{lrrrrrr}
\hline & \multicolumn{1}{c}{ BOPO } & \multicolumn{1}{c}{ CAR } & LNSIZE & PDRBT & GCREDR & \multicolumn{1}{c}{ INFR } \\
\hline BOPO & 1 & $-0,429$ & 0,178 & $-0,01$ & $-0,09$ & $-0,097$ \\
CAR & $-0,429$ & 1 & $-0,423$ & 0,005 & 0,125 & 0,169 \\
LNSIZE & 0,178 & $-0,423$ & 1 & $-0,287$ & $-0,087$ & $-0,261$ \\
GPDRBT & $-0,01$ & 0,005 & $-0,287$ & 1 & 0,103 & $-0,148$ \\
GCREDR & $-0,09$ & 0,125 & $-0,087$ & 0,103 & 1 & 0,187 \\
INFR & $-0,097$ & 0,169 & $-0,261$ & $-0,149$ & 0,187 & 1 \\
\hline
\end{tabular}

Tabel 9

Uji Heteroskedastisitas

Heteroskedasticity Test: Breusch-Pagan-Godfrey

F-statistic

1,695 Prob. F(6,123)

0,128

Obs*R-squared

9,9278 Prob. Chi-Square(6)

0,128

Scaled explained SS

12,431 Prob. Chi-Square(6)

0,053

Test Equation:

Dependent Variable: RESID^2

Method: Least Squares

Date: 06/01/14 Time: 00:54

Sample: 1130

Included observations: 130

Newey-West HAC Standard Errors \& Covariance (lag truncation=4)

\begin{tabular}{crrrc}
\hline Variable & Coefficient & Std. Error & t-Statistic & Prob. \\
\hline C & 0 & 0 & 1,728 & 0,086 \\
BOPO & $-5,55 \mathrm{E}-05$ & $5,70 \mathrm{E}-05$ & $-0,974$ & 0,332 \\
CAR & $4,94 \mathrm{E}-05$ & 0 & 0,272 & 0,786 \\
LNSIZE & $-1,30 \mathrm{E}-05$ & $7,95 \mathrm{E}-06$ & $-1,636$ & 0,104 \\
PDRBT & 0 & 0 & 1,317 & 0,190 \\
GCREDR & $-2,84 \mathrm{E}-05$ & $3,80 \mathrm{E}-05$ & $-0,749$ & 0,455 \\
INFR & 0 & 0 & $-0,9$ & 0,37 \\
\hline
\end{tabular}

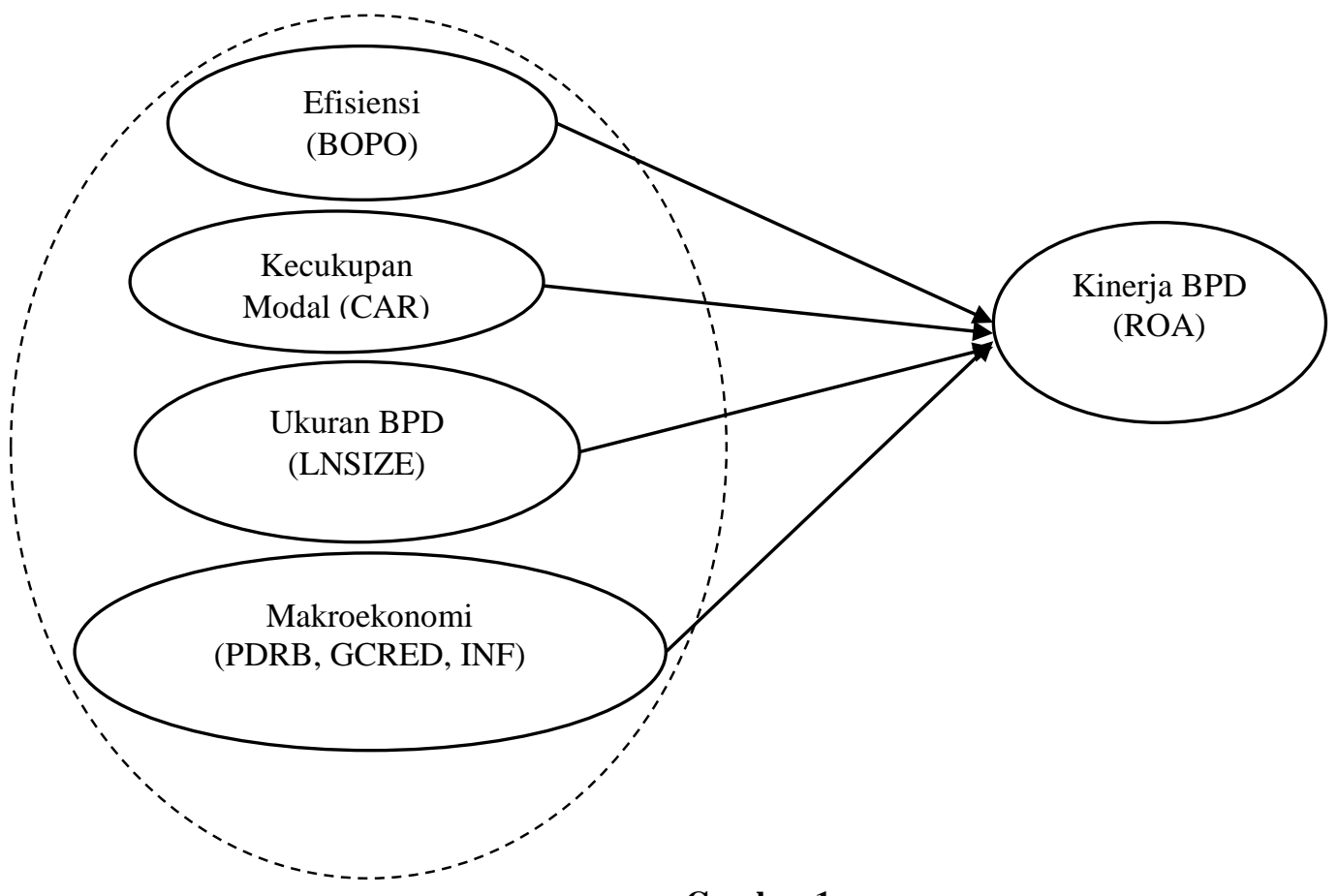

Gambar 1

Kerangka Pemikiran 


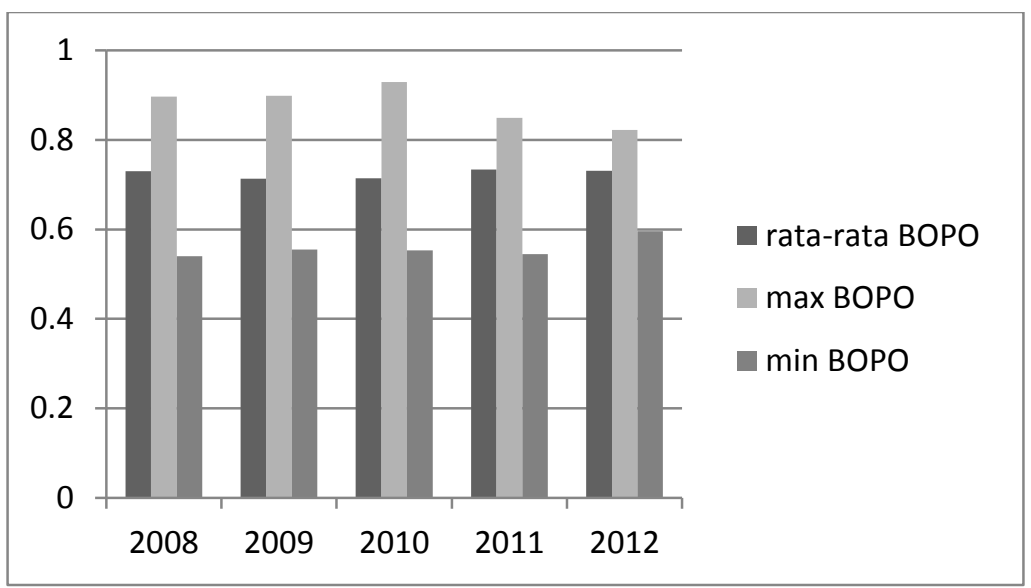

Gambar 2

Rata-rata, Max, dan Min BOPO per tahun 2008-2012 
